\section{IJ§ER}

ISSN: 2149-5939
International Journal of Social Sciences and Education Research

Online, http://dergipark.gov.tr/ijsser

Volume: 3(4), 2017

\title{
Determining the impact of brand equity on consumer purchase intention
}

\author{
Vesile Özçifçi ${ }^{1}$
}

Received Date: 20 /03/ 2017

Accepted Date: $18 / 06 / 2017$

\begin{abstract}
In this study, it was attempted to determine which brand equity element is more effective regarding the mobile phone purchase of university students. Brand equity is defined in three dimensions which are brand awareness, perceived quality and brand loyalty. Data was collected by 1190 subjects studying at the faculties of Aksaray University. The data was tested by Structural Equation Modeling. As a result of the research, it was found that brand awareness affects perceived quality, but it does not affect the brand loyalty and overall brand value. Perceived quality affects brand loyalty and overall brand value, while the brand loyalty affects the overall brand value. Furthermore, it was found that overall brand value affects purchase intention.
\end{abstract}

Keywords: Brand Equity, Overall Brand Equity, Purchase Intention. Structural Equation Modelling

\section{Introduction}

Globalization and rapid transformation in technology, together with the change in consumers' desires and needs, have brought out a proliferation in substitute products and the emergence of international brands that compete in different markets. The brand that shapes the consumers' purchase decisions is the focal point of enterprises' marketing operations. There are various definitions of the brand. The brand, according to the definition by American Marketing Association, is a name, term, marker, symbol or design or a combination of these that are determined by a seller or group of sellers in order to differentiate their products and/or services from the competitors.

The brand, beyond the functional aims, is a name, symbol, design or marker that increases the equity of a product. Depending on what aspect it is taken into consideration, it provides an added value to both the enterprise and consumers (Farquhar, 1989, p. 25). Nevertheless, the power of the brand depends on consumers' perspective and experiences (Mills \&Williams, 2016, p. 121).

Brand equity continues to be dominant in marketing researches in recent years. The main reason why brand equity is so dominant in marketing research is marketers' desire of creating a powerful brand in order to gain sustainable competitive advantage and differentiate their products from their competitors (Latha, 2016, p. 18).

It is still questioned how to determine the equity that the brand stands for and what its scope and limits are. Understanding the brand equity precisely helps to detect consumers' brand tendencies and behaviors and to develop products and services accordingly. Studies show that the first condition for a brand to create a financial equity is to create an equity in consumers' minds (Ural \& Perk, 2012, p. 12).

Although they have become a daily tool, mobile phones are shopping items that consumers purchase in medium and high levels. Therefore, consumers spend great effort in decision-making

\footnotetext{
${ }^{1}$ Asst. Prof. Dr., Aksaray University, Aksaray/TURKEY, vesile.ozcifci@yahoo.com 
Özçifçi, V. (2017). Determining the impact of brand equity on consumer purchase intention. International Journal of Social Sciences and Education Research, 3 (4), 1164-1177.

processes in obtaining such products. As a result, many factors are taken into account before, during and after buying a mobile phone brand (Odoom, 2016, p. 652). Studies indicate that young consumers form the majority of the market and they are more innovative. The innovations in the field of mobile phones emerges particularly rapidly. In Turkey, according to 2015 Target Group Index (TGI) data, the ratio of mobile phone owning people who are over 15 years old has reached $90 \%$ with a $3 \%$ increase from the previous year. One out of every three individuals is said to have a smart phone in Turkey (www.connectedvivaki.com/turkiyede-medya-tuketim-trendleri-infografik/,Retrieved on:31.04.2017). Mobile phones were selected as a product group for this study in this context. In this study, a consumer oriented brand equity approach (brand equity from now on) was used. Building upon this objective, the relation among brand equity dimensions, the effect of these dimensions on overall brand equity and the effect of overall brand equity on purchase intention have been examined. Besides, the study investigates which of these components of brand equity affect purchase decisions.

\section{Literature review}

Brand equity is the value added to the product by the brand (Farquhar, 1989, p. 24). Vazquez et al (2002, p. 28) define brand equity as a symbolic and functional benefit that the consumer relates through utilizing and consuming the brand. The term, brand equity, is widely conceptualized by Aaker (1991) and Keller (1993). Aaker (1991, p. 15) describes brand equity, as "a set of brand assets and liabilities linked to a brand, its name and symbol that add too or subtract from the value provided by a product or service to a firm and/or to that firm's customers". According to Keller (1993), brand equity is the differential effect that brand knowledge has on consumer response to the marketing of that brand. Brand equity is the value that the consumer relates to a brand; the power of the brand is shaped as a reaction of the consumers to what they learn, feel and hear about the brand in time (Keller, 2013, p. 69). Yoo et al (2000, p. 195) define brand equity as the incremental utility or value added to a product by its brand name. Besides being a major concept of marketing, brand equity has become a distinguishing marketing strategy in all industries. While there are comprehensive studies on brand equity, the literature on this topic is highly divided and inadequate. Although there is a huge effort on and interest in forming the conceptual framework of brand equity subject, the debate continues. Some researchers think that there is a lack of general theoretical framework on the topic (Taşkın \& Akat, 2010; Buil et al, 2013; Avcılar, 2008). The majority of the researches on brand equity deals with the topic in consumers' point of view while some do it in financial terms. Brand equity, financially, is thought as the financial value of a brand for a firm (Rasouli, 2016, p. 38). Consumer based brand equity, on the contrary, describes consumers' awareness of a brand (Buil et al, 2013, p. 63). The power of a brand depends on consumers' attitudes and experiences (Mills \& Williams, 2016, p. 121). Financial methods are criticized for not including all the elements that form the power of the brand and for not taking consumer behaviors and tendencies into consideration. Therefore, models that construct brand equity with regard to the consumer and attempt to represent consumer preference on the brand have been developed (Marangoz, 2007, p. 462).

Brand equity is a value that is created by enhancing the effectiveness of marketing operations, brand preference, desired purchase intention and market share of a firm (Majid et al, 2016:32). As the brand equity increases so does the industrial users' willingness of buying the brand repeatedly and paying more. As a result, the enterprise with a high-valued brand may bring benefits 
Özçifçi, V. (2017). Determining the impact of brand equity on consumer purchase intention. International Journal of Social Sciences and Education Research, 3 (4), 1164-1177.

both for itself and the others in the market. These benefits constitute the elements that create competitive advantage for the enterprise (Ural \& Perk, 2012, p. 12).

As the international brands have spread out together with the globalization, the enterprises have focused on how to manage their brands. As a result, a powerful brand value that is created by the enterprise has become one of the most imperative competition tools that define consumers' preferences and re-purchase. Therefore, it has gained importance to measure the dimensions of the brand equity as much as examining it conceptually (Aaker, 1991; Keller 1993; Aaker, 1996; Kim \& Kim 2004; Pappu et al, 2005; Atılgan et al, 2005; Keller, 2013; Ahmad \& Sherwani, 2015; Özdemir \& Güzeloğlu, 2015; Girard et al, 2017).

\section{The Dimensions of brand equity}

The dimensions that create brand equity also change depending on the researchers. The studies that deal with brand equity have been carried out in different dimensions by different researchers. Farquhar (1989) explains the dimensions of brand equity as brand image, attitude towards the brand and brand assessment. Aaker (1991) categorizes these dimensions as brand awareness, brand association, brand loyalty, perceived quality and other special brand entities. Keller (1993) examines the brand equity dimensions under two attributes that are brand knowledge and image. Some researchers have conceptualized brand equity similar to Aaker (1991) and identified its four dimensions as brand awareness, brand association, perceived quality and brand loyalty (Kim et al, 2003; Pappu et al, 2005; Marangoz, 2007; Gill \& Dawra, 2010; Ural \& Perk, 2012; Ahmad \& Sherwani, 2015; Özdemir \& Güzeloğlu, 2015; Tanveer \& Lodhi, 2016).

Swait et al (1993) have developed a model that uses the benefits which consumers try to receive as a base for the effect of brand name, cost, product features, brand image and consumer differences. Park and Srinivasan (1994) try to figure out brand equity at consumer level. Lassar and his collaborators (1995) develop a brand equity scale that consists of five dimensions, namely performance, social image, value, reliability and loyalty that the brand provides (Koçak \& Özer, 2004:193).

Konecnik and Gartner (2007) figure out brand equity as brand awareness, brand image, perceived quality and brand loyalty while Madhavaram et al (2005) and Jara \& Cliquet (2012) do it as brand image and awareness.

Yoo et al (2000) have constructed Aaker's (1991) fundamental brand equity model in figuring out brand equity. After determining that there is no disintegration validity for brand awareness and brand association dimensions, they have combined these two dimensions and explained that brand equity consists of three aspects as brand loyalty, brand awareness/associations and perceived quality.

Yoo and Donthu (2001) were also the first to develop a multidimensional scale for consumerbased brand equity and test its psychometric properties. These researchers observed only three dimensions for consumer-based brand equity, similar to Yoo et al. (2000). Yoo and Donthu's (2001) consumer-based brand equity scale was later validated by Washburn and Plank (2002). While these two dimensions are conceptually different (e.g. Aaker, 1991), some empirical evidence (e.g. Yoo \& Donthu, 2001, 2002; Yoo et al., 2000; Washburn \& Plank, 2002) suggests that they should be combined into one (Pappu et al., 2005, p. 144). On the other hand, there are also studies that deal with the brand equity under three headings in the literature (Baldauf et al, 2003; 
Özçifçi, V. (2017). Determining the impact of brand equity on consumer purchase intention. International Journal of Social Sciences and Education Research, 3 (4), 1164-1177.

Kim \& Hyun, 2011; Loureiro 2013; Saydan 2013; Yılmaz \& Bağdigen, 2015; Can, 2016) in which the brand equity has been conceptualized in three dimensions parallel to Yoo et al (2000).

\subsection{Brand awareness}

Brand awareness and brand association are the dimensions that underlie brand knowledge. Consumers' decision-making process is effected by the products and services that stay in consumers' minds in longer periods and that the consumers are aware of (Shafi \& Madhavaiah, 2014:36). Brand awareness affects consumers' decision-making process by affecting the formation and power of brand associations (Keller, 1993, p. 3). Brand awareness is the first step in creating brand equity. This dimension refers to if consumers remember a product and if the existence of a product depends on its power in consumers' mind. Besides, it contains various mental associations about the brand. First, consumers become aware of a brand. Then, they have brand associations. What is more, brand awareness affects the formation and power of perceived quality. Therefore, brand awareness dimension is a major premise of the perceived quality (Aaker, 1991; Keller, 2003; Loureiro, 2013; Ahmad \& Sherwani, 2015; Can, 2016). In this context, the hypothesis- 1 can be stated as follows $\left(\mathrm{H}_{1}\right)$;

$\mathrm{H}_{1}$ : Brand awareness has an effect on perceived quality.

Brand awareness is shown as one of the most important dimensions that determine the brand equity (Bilgili \& Özkul, 2015, p. 91). Consumers use a brand depending on their knowledge and experiences. Therefore, when consumers become aware of a product through their experiences, they propose others to buy that brand. This makes the brand stronger. Consumers tend to think that the most well-known brand is more reliable than less known ones when they choose a product. Many researchers advocate that reliable advertising definitely changes consumer behaviors related to the brand. Consumers have more knowledge on the product as they learn about the brand through advertisements. Hence, when consumers buy a product, they have more knowledge about the brand and an image of the brand is created (Khan et al, 2016, p. 3). Besides, Pappu and Quester (2006) state that when there is no product awareness, consumers cannot have an association with the quality and image of the brand, so brand loyalty cannot occur; brand awareness should be provided in order to create brand equity (Ural \& Perk, 2012, p. 14) In this context, hypothesis 2 and 3 have been developed as:

$\mathrm{H}_{2}$ : Brand awareness has an effect on brand loyalty.

$\mathrm{H}_{3}$ : Brand awareness has an effect on overall brand equity.

\subsection{Perceived quality}

Zeithaml (1998) define perceived quality as consumer judgements about a brand in terms of its superiority, prestige and difference compared to its competitors. Perceived quality is not the product's real quality, but consumers' judgements about the superiority or excellence of the product performance as a result of subjective assessments by themselves (Avc1lar, 2008, p. 14).

A high quality perception emerges when consumers distinguish the difference and superiority of a brand compared to its competitors. Thus, it affects consumers' purchase decisions and force them to buy that specific brand among the others. A high quality perception affects consumers' preferences, thus it causes an increase in brand equity. Besides, it can support primary price and this may create a higher profit margin (Yasin et al, 2007, p. 40). 
Özçifçi, V. (2017). Determining the impact of brand equity on consumer purchase intention. International Journal of Social Sciences and Education Research, 3 (4), 1164-1177.

Perceived quality affects not only the other dimensions of the brand but also consumers' perspective and the categorization of the products (Majid et al, 2016, p. 32). Perceived quality and brand association are primary steps in creating brand loyalty. Brand loyalty is a deep loyalty to the brand. Consumers' very high positive perception towards the brand provides brand loyalty (Aaker, 1991; Keller \& Lehmann, 2003).

Researches indicate that perceived quality affects brand equity (Yoo et al, 2000; Baldaufet al, 2003; Ahmad \& Sherwani, 2015; Taşkın, 2016; Ural \& Perk, 2012), and a high quality perception increases brand loyalty (Aaker, 1991; Keller \& Lehmann, 2003; Baldauf et al, 2003 Taşkın, 2016; Buil et al, 2013). In this context, hypothesis 4 and 5 have been developed as

$\mathrm{H}_{4}$ : Perceived quality has an effect on brand loyalty.

$\mathrm{H}_{5}$ : Perceived quality has an effect on overall brand equity.

\subsection{Brand loyalty}

Loyalty is an important marketing strategy. According to Solomon (1990), purchase decisions that rely on loyalty can turn into habits and this might be caused by existing brand equity. A loyal customer provides benefits to the enterprise such as decreasing operating costs. Besides, loyalty creates an opportunity for the enterprises to react to the competition. When consumers have loyalty on a product, they are less sensitive to the increases in product price because of product's ability to fulfill his/her needs (Ahmad \& Sherwani, 2015, p. 61).

Aaker (1991, p. 39) describes brand loyalty as the measurement of the consumer's loyalty on the brand. Brand loyalty is the consumers' preference of purchase a specific brand in a product category. Brand loyalty emerges when consumers perceive that the brand presents proper product features and proper image or quality at a proper price. This perception may turn to re-purchase that creates the loyalty. Therefore, brand loyalty is related to the preference and loyalty of a customer to a brand (Ishak \& Ghani, 2013, p. 186). Brand loyalty has the power of purchase the same product or brand and effecting customer decisions against the competing brands. Besides, it impels a customer to buy a brand regularly and to resist switching to another brand. In other words, brand value increases parallel to its customers' loyalty on the brand (Yoo et al, 2000, p. 197).

Brand value is a value that is created through escalated marketing activities, brand preferences, desired purchase intention and market share of a firm. For example, if a brand has an especially high value, target consumers will have a positive behavior towards the brand. As a result, the customer will be willing to pay a higher price for it, re-purchase and promote it (Majid et al, 2016, p. 31-32). The brand equity is generally created by brand loyalty. If customers have loyalty to a brand against competing brands with superior features, it means that this brand has an important value for customers (Yasin et al, 2007, p. 39).

Studies show that brands with higher brand equity create brand loyalty on the customers (Yoo et al, 2000; Atılgan et al, 2005; Pappu \& Quester, 2006; Yasin et al, 2007; Ural \& Perk, 2012; Sasmita \& Suki, 2015; Taşkın, 2016). Aaker (1991) indicates that customers' loyalty on a specific brand is the most important factor which affects brand equity. Kotler explains brand equity is high when customer loyalty is high. As brand equity is related to the other factors that affect brand equity, it has a positive effect on brand equity (Ural \& Perk, 2012:15). 
Özçifçi, V. (2017). Determining the impact of brand equity on consumer purchase intention. International Journal of Social Sciences and Education Research, 3 (4), 1164-1177.

Customers are supposed to purchase the products by the brands that is more valued, known and heard beforehand, trusted and positively associated, and believed to have a high quality (Ural \& Perk, 2012; Buil et al, 2013; Lakshmi \& Kavida, 2016). Therefore, the relation between brand equity and purchase intention is included in the model. Depending on the explained claims, hypothesis 6 and 7 have been developed:

$\mathrm{H}_{6}$ : Brand loyalty has an effect on overall brand equity.

$\mathrm{H}_{7}$ : Overall brand equity has an effect on purchase intention.

\section{Methodology}

\subsection{The aim of the study}

This study examines the relations among the brand equity dimensions (brand loyalty, brand awareness and perceived quality), how they affect overall brand equity and the effect of overall brand equity on purchase intention. The relation between brand equity dimensions and overall brand equity have been analyzed in the literature review (Yoo et al, 2000; Keller \& Lehman, 2003; Atılgan et al, 2005; Kocaman \& Güngör, 2012; Yılmaz \& Bağdigen, 2015). However, a limited number of studies empirically researched so far how brand equity dimensions are related to each other.This study is supposed to contribute to the field in this context. Besides, the evaluation of mobile phone brand equity dimensions is examined in the literature (Keskin \& Y1ldiz, 2010; Sasmita \& Suki, 2015; Ahmad \& Sherwani, 2015; Özdemir \& Güzeloğlu, 2015).

Özdemir and Güzeloğlu (2015) have carried out a survey in order to find out if there is a difference in brand equity components of the young and their families. The data shows that there is a difference between the two. Consequently, brand loyalty, social effect, quality and trust are important factors for the young in brand equity.

In their study with Generation-Z, Özkan \& Solmaz (2015) have found out that smart phone use is not an addiction but an important part of their life. In this context, the university students'evaluation of the mobile phones is also examined in order to determine the relations among brand equity dimensions, their effect on the overall brand equity and the effect of overall brand equity on the purchase intention.

The research model that is developed through the examinations in the literature review part is shown in Figure-1.

Figure 1. Research model

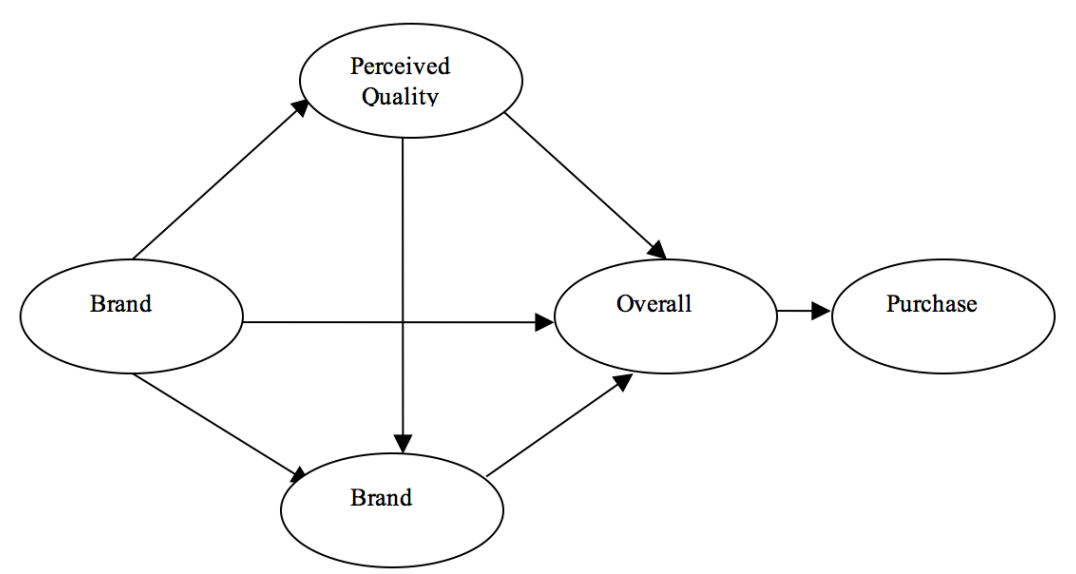


Özçifçi, V. (2017). Determining the impact of brand equity on consumer purchase intention. International Journal of Social Sciences and Education Research, 3 (4), 1164-1177.

\subsection{Data collection and sample}

The data has been collected through a survey. The number of sample has been determined considering the features of the study, the number of variables in the study, the features of the analysis that would be used in the study and number of sample that have been used in similar studies (Nakip, 2004:137-138; Altunışık et al, 2004, p. 124-125). Besides, employing structural equation modelling in the analysis has been taken into consideration while deciding the number of sample and the number has been tried to be maximized in order to provide more valid and reliable data. The sampling has been done through quote sampling method and includes 1190 students from seven faculties of Aksaray University. The data analysis was carried out through AMOS and SPSS programs.

The questions on the variables that are in the research model were formed from the questions that have been used in the literature before. The information such as gender, age, faculty, mobile phone change frequency, and most remembered mobile phone brand is used as personal features. The items related to brand loyalty dimension of brand equity are taken from the studies of Yoo et al (2000) and Kim et al (2003); items related to brand awareness and association, perceived quality dimension is taken from the study of Yoo et al (2000); the items related to overall brand equity are taken from the studies of Yoo et al (2000); the items related to purchase intention are taken from the study of Erdem et al (2006). A five point likert scale that is graded from 1=definitely disagree to $5=$ definitely agree was used to collect participants' answers.

\section{Findings}

The demographic information of the participants, validity and reliability analysis results and the results of structural equation modelling that is used to test the hypothesis are given in this part of the study.

The information about the 1190 participants is given in Table- 1 below:

Table 1. The demographics of the participants

\begin{tabular}{llcc}
\hline Demographic Information & & F & \% \\
\hline Gender & Female & 643 & 54 \\
Age & Male & 547 & 46 \\
& $18-22$ & 891 & 74.9 \\
Faculty & $23-27$ & 281 & 23.6 \\
& $28-32$ & 18 & 1.5 \\
& Engineering & 408 & 34.3 \\
& Economics \& Administrative Sci- & 370 & 31.1 \\
& ences & & \\
& Science and Letters & 228 & 19.2 \\
Mobile Phone Change & Education & 120 & 10.1 \\
Frequency & Islamic Sciences & 36 & 3.0 \\
& Tourism & 19 & 1.6 \\
& Veterinary & 9 & 0.7 \\
& Less than 6 months & 15 & 1.3 \\
Most Remembered Brands & Between 6 months and 1 year & 70 & 5.9 \\
& 1-2 years & 343 & 28.8 \\
& 2-3 years & 353 & 29.7 \\
& More than 3 years & 409 & 34.3 \\
& Samsung & 480 & 40.3 \\
& Apple & 290 & 24.4 \\
& Nokia & 232 & 19.5 \\
& LG & 55 & 4.6 \\
& Sony & 46 & 3.9 \\
& Others & 87 & 7.3 \\
\hline
\end{tabular}


Özçifçi, V. (2017). Determining the impact of brand equity on consumer purchase intention. International Journal of Social Sciences and Education Research, 3 (4), 1164-1177.

\subsection{The validity and reliability of the scales}

The exploratory factor analysis was carried out in order to determine the dimensions of the scales within the model.The exploratory factor analysis aims to define the fundamental structure within a data matrix and determine the dimensions that form this structure (Hair et al, 1998, p. 90). In the exploratory factor analysis, principal components analysis and varimax rotation methods were used in calculating factor loadings and factors' having an eigenvalue higher than 1 and factor loadings' being higher than 0.50 were used as conditions in the determination of the dimensions (Hair et al, 1998; Sakakibara et al, 1993).

First, corrected total correlation of the items that form the scales were examined; one item in the brand awareness scale was excluded from the analysis as its values were lower than 0.40. Kaiser-Meyer-Olkin (KMO) value that determines the appropriateness of the scales to the exploratory factor analysis was calculated and it was found as 0.931 for Brand Equity Scale; 0.835 for Overall Brand Equity Scale; 0.735 for Purchase Intention Scale. KMO value is expected to be higher than 0.50 for factor analysis (Chong \& Rundus, 2004; Tabanick \& Fidell, 2001, p. 589). Besides, Bartlett's Sphericity Test values that show the appropriateness of the data to the factor analysis are $\chi^{2}=8217.875(p<0.05)$ for Brand Equity Scale; $\chi^{2}=2559.576(p<0.05)$ for Overall Brand Equity Scale; $\chi^{2}=1835.528(p<0.05)$ for Purchase Intention Scale. These results indicate that the data is appropriate for exploratory factor analysis.

According to the exploratory factor analysis results that is given in Table-2, Brand Equity Scale consists of three dimensions that are Brand Loyalty, Brand Awareness and Perceived Quality. These dimensions are compatible with the dimensions determined by Yoo et al, (2000) in the original scale.

The total explained variance (VE) of the Brand Equity Scale is $65 \%$. When explained variance values of each dimension are examined, the brand equity is explained by $19.099 \%$ by Brand Loyalty, $20.019 \%$ by Brand Awareness and $25.883 \%$ by Perceived Quality (Table 2 ).

To test the internal consistency of the scales, Cronbach alpha coefficient $(\alpha)$ has been used in the study. The scale is said to have high internal consistency if Cronbach alpha value is 0.70 or above (Nunnally, 1978). Cronbach alpha values for each dimension is given in Table-2. Internal consistency analysis result shows that it is $\alpha=0.804$ for Brand Loyalty, $\alpha=0,833$ for Brand Awareness and $\alpha=0,882$ for Perceived Quality.The internal consistency of each dimension is $\alpha>0.70$. These results indicate that the dimensions of brand equity scale are reliable and measure the intended feature correctly with a high probability.

To test the research hypothesis, structural equation modelling has been used. The model's statistical validity should be tested before starting testing the hypothesis within the research model through the structural equation modelling. The goodness of fit values of the measurement model was given in Table-3.

According to the results given in Table- 3 , the value obtained by dividing $\chi^{2}$ to degree of freedom is supposed to be two or lower. It is an acceptable value if it is five or lower (Hooper and Mullen, 2008, p. 54). The obtained results show that all fitness indexes of the structural equating modelling are within the good fitness limits (Zhang et al, 2006; Ayyıldız et al, 2006; Rao \& Holt, 2005; Prahinski \& Fan, 2007; Veronique et al, 2007). As a result, the model is statistically significant and valid. Besides, all values that will be used to test the hypothesis are statistically useable. 
Özçifçi, V. (2017). Determining the impact of brand equity on consumer purchase intention. International Journal of Social Sciences and Education Research, 3 (4), 1164-1177.

Table 2. Exploratory factor analysis of brand equity scale

\begin{tabular}{|c|c|}
\hline \multirow{2}{*}{\multicolumn{2}{|c|}{$\begin{array}{ll}\text { Scale/Items } & \text { Factor } \\
\text { Brand Loyalty }(\alpha=0.804 ; V E=19.099) & \end{array}$}} \\
\hline & \\
\hline BL1-This brand would be my first choice. & 0.582 \\
\hline BL2- I will not buy other brands if this brand is available at the store. & 0.818 \\
\hline BL3- I consider myself to be loyal to this brand. & 0.797 \\
\hline BL4- If I buy a new mobile phone, I prefer this brand again. & 0.664 \\
\hline BL5- I would recommend this brand to others. & 0.528 \\
\hline \multicolumn{2}{|l|}{ Brand Awareness $(\alpha=0.833 ; \mathrm{VE}=20.019)$} \\
\hline BA1- I can recognize the brand among other competing brands. & 0.715 \\
\hline BA2- I know what this brand looks like. & 0.865 \\
\hline BA3- I am aware of this brand. & 0.783 \\
\hline BA4- I can quickly recall the symbol or logo of this brand. & 0.660 \\
\hline \multicolumn{2}{|l|}{ Perceived Quality $(\alpha=0.882 ; \mathrm{VE}=25.883)$} \\
\hline PQ1- This brand is of high quality. & 0.769 \\
\hline PQ2-The likelihood that this brand would be functional is very high. & 0.790 \\
\hline PQ3-The likelihood that this brand is reliable is very high. & 0.765 \\
\hline PQ4- The design of this brand is more attractive. & 0.699 \\
\hline PQ5- This brand fulfills my expectations from a mobile phone. & 0.699 \\
\hline \multicolumn{2}{|l|}{$\begin{array}{l}\mathrm{N}=1190 ; \mathrm{KMO}=0.931 \\
\text { Bartlett's Sph. } \chi^{2}=8217.875 \text { and } \mathrm{p}<0.05\end{array}$} \\
\hline \multicolumn{2}{|l|}{ Total Explained Variance $=0,65$} \\
\hline \multicolumn{2}{|l|}{ Overall Brand Equity $(\alpha=0.882 ; \mathrm{VE}=73.976)$} \\
\hline $\begin{array}{l}\text { OBE1-Even if another brand has same features as this brand, I would prefer to buy this } \\
\text { brand. }\end{array}$ & 0.864 \\
\hline OBE2-If there is another brand as good as this brand, I prefer to buy this brand. & 0.879 \\
\hline $\begin{array}{l}\text { OBE3-If another brand is not different from this brand in any way, it seems smarter to } \\
\text { purchase this brand. }\end{array}$ & 0.887 \\
\hline OBE4-It makes sense to buy $X$ instead of any other brand, even if they are the same. & 0.808 \\
\hline \multicolumn{2}{|l|}{$\begin{array}{l}\mathrm{N}=1190 \mathrm{KMO}=0.835 \\
\text { Bartlett's Sph. } \chi^{2}=2559.576 \text { and } \mathrm{p}<0.05\end{array}$} \\
\hline \multicolumn{2}{|l|}{ Purchase Intention $(\alpha=0.874 ; \mathrm{VE}=79.930)$} \\
\hline PI1-I would buy this brand. & 0.886 \\
\hline PI2-I would seriously consider buying this brand. & 0.885 \\
\hline PI3-It is very likely that I would buy this brand. & 0.911 \\
\hline $\begin{array}{l}\mathrm{N}=1190 \mathrm{KMO}=0.735 \\
\text { Bartlett's Sph. } \chi^{2}=1835.528 \text { and } \mathrm{p}<0.05\end{array}$ & \\
\hline
\end{tabular}

The structural equation model to which required modifications were done is given in Figure2. Arrows in Figure-2 represent the relations among the variables. The values on these arrows are standardized regression coefficients.

Table 3. Goodness of Fit Indexes of the measurement model

\begin{tabular}{lllc}
\hline Fitness Indexes & \multicolumn{1}{c}{ Good Fitness } & \multicolumn{1}{c}{$\begin{array}{c}\text { Acceptable } \\
\text { Fitness }\end{array}$} & $\begin{array}{c}\text { Research } \\
\text { Model }\end{array}$ \\
\hline$\chi^{2} / \mathrm{df}$ & $\chi^{2} / d f<2$ & $\chi^{2} / d f<5$ & 4.024 \\
$\mathrm{GFI}$ & $0.95 \leq \mathrm{GFI} \leq 1$ & $0.90 \leq \mathrm{GFI} \leq 0.95$ & 0.945 \\
$\mathrm{AGFI}$ & $0.90 \leq \mathrm{AGFI} \leq 1$ & $0.85 \leq \mathrm{AGFI} \leq 0.90$ & 0.928 \\
$\mathrm{NFI}$ & $0.95 \leq \mathrm{NFI} \leq 1$ & $0.90 \leq \mathrm{NFI} \leq 0.95$ & 0.953 \\
$\mathrm{CFI}$ & $0.97 \leq \mathrm{CFI} \leq 1$ & $0.95 \leq \mathrm{CFI} \leq 0.97$ & 0.964 \\
$\mathrm{RMSEA}$ & $0<\mathrm{RMSEA}<0.05$ & $0.05 \leq \mathrm{RMSEA} \leq 0.10$ & 0.05 \\
\hline
\end{tabular}


Özçifçi, V. (2017). Determining the impact of brand equity on consumer purchase intention. International Journal of Social Sciences and Education Research, 3 (4), 1164-1177.

Figure 2. Model for measuring the relationships between brand equity dimensions and overall brand equity and purchase intention

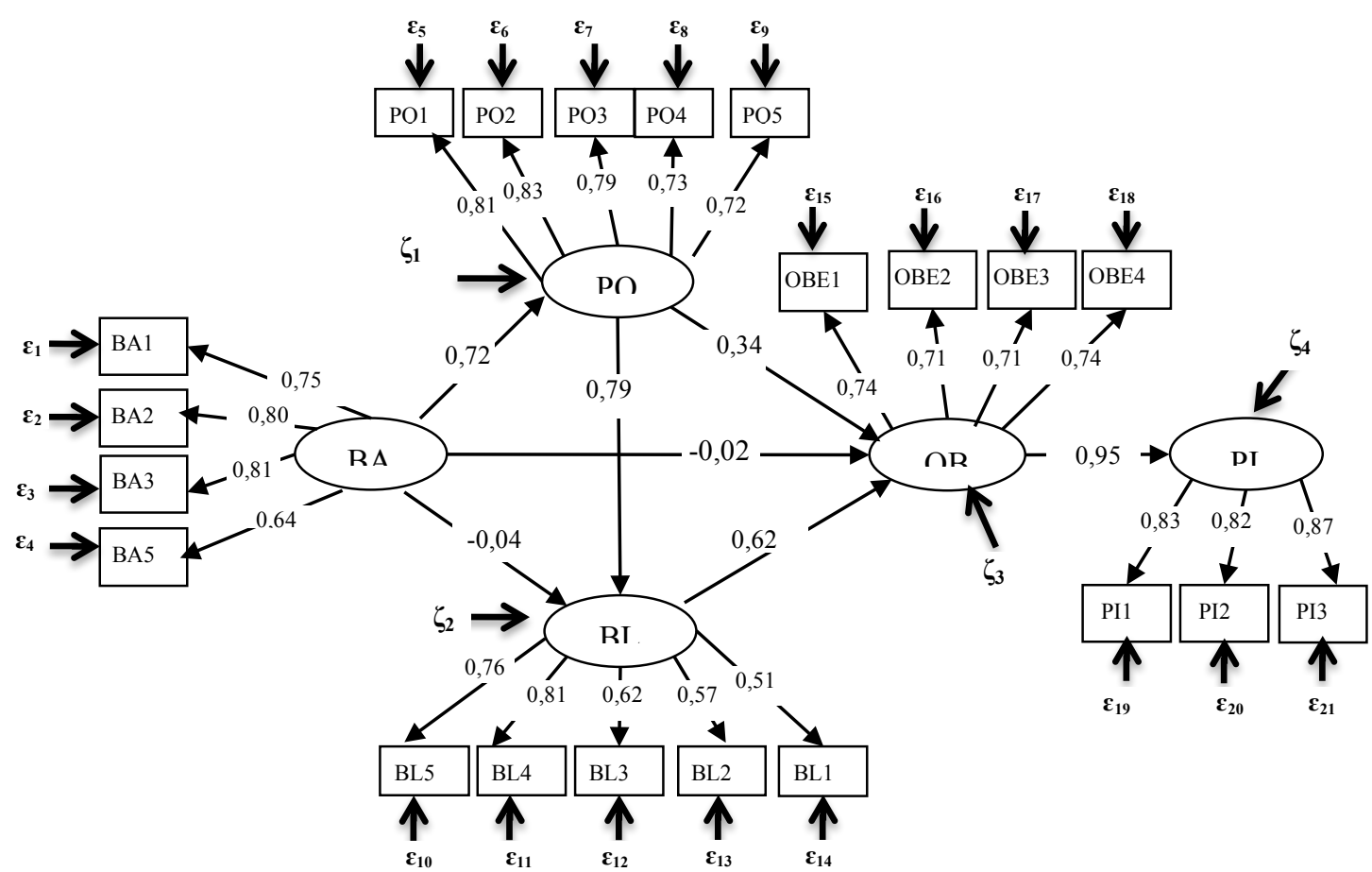

Not: BA: Brand Awareness, PQ: Perceived Quality, BL: Brand Loyalty, OBE: Overall Brand Equity, PI: Purchase Intention

As seen in Figure-2, the correlation coefficient of brand awareness and perceived quality is $0.72(\mathrm{p}<0.05)$. According to this finding, $\mathrm{H}_{1}$ is accepted. On the other hand, the correlation coefficient of brand awareness and brand loyalty is -0.04 ( $p>0.05)$. As a result, $\mathrm{H}_{2}$ is rejected. The correlation coefficient of brand awareness and overall brand equity is $-0.02(p>0.05)$. Accordingly, $\mathrm{H}_{3}$ is rejected. For the correlation coefficient of perceived quality and brand loyalty is 0.79 $(\mathrm{p}<0.05), \mathrm{H}_{4}$ is accepted. The correlation coefficient of perceived quality and overall brand equity is 0.34 ( $\mathrm{p}<0.05$ ), so $\mathrm{H}_{5}$ is accepted. The correlation coefficient of brand loyalty and overall brand equity is $0.62(\mathrm{p}<0.05)$. As a result, $\mathrm{H}_{6}$ is accepted. Finally, the correlation coefficient of overall brand equity and purchase intention is $0.95(\mathrm{p}<0.05)$, so $\mathrm{H}_{7}$ is accepted.

Furthermore, according to structural equation model, the brand loyalty dimension has the highest impact on overall brand equity.

\section{Results and suggestions}

This study investigates the relations among consumer based brand equity dimensions, the effect of these dimensions on overall brand equity and the effect of overall brand equity on purchase intention. After validity and reliability analysis of the scales was performed, seven basic hypotheses that had been developed in accordance with the purpose and model of the study were tested through structural equation model.

The results of the study indicate that brand awareness has a statistically significant and positive effect on perceived quality. This result is compatible with the findings of some other studies in the literature (Buil et al, 2013; Ural \& Perk, 2012; Ahmad \& Sherwani, 2015). It has been found 
Özçifçi, V. (2017). Determining the impact of brand equity on consumer purchase intention. International Journal of Social Sciences and Education Research, 3 (4), 1164-1177.

out that brand awareness has no effect on overall brand equity. This result is similar to findings of Loureiro (2013), Atılgan et al (2005) and Işık (2016). Furthermore, it has also been found that the brand awareness has no effect on brand loyalty.

According to the results, perceived quality acts on brand loyalty (Taşkın, 2016) and overall brand equity (Tanveer \& Lodhi, 2016; Buil et al, 2013). Besides, brand loyalty affects overall brand equity (Buil et al, 2013; Yasin et al,2007; Ahmad et al,2015; Sasmita \& Suki, 2015) and overall brand equity affects purchase intention (Ural \& Perk,2012; Lakshmi \&Kavida, 2016). Additionally, brand loyalty is the dimension that has the highest effect on overall brand equity. This result is compatible with findings of Yoo et al (2000).

The results indicate that there is not a big difference in consumers' minds in terms of mobile phone brands when they compare similar product brands, so it can be concluded that there is not a powerful brand image. This can be caused by collecting the data from a student group of whose data is homogenous and choosing mobile phone as a product category. The immense developments in communication technologies in recent decades has made mobile phones an inevitable part of people's lives. The usage of smart phones is increasing as a great deal of functions can be carried out through them. Besides, many alternatives are provided to the consumers. Brand loyalty cannot be provided when there isn't any brand awareness. As Rosser Reeves, the world's most successful advertiser, says, "The true owner of a brand is not the companies that created it, but the customers who have allocated a space in their memories for it". In this context, with the changing nature of today's consumers, it is getting increasingly difficult for businesses to control their own brands. Today, brands' life curves also shift (Karahasan, 2012:132-134). Hence, businesses need to be able to generate an environment in which consumers share their feelings and values. Accordingly, they can raise awareness of their brand through advertisements and personal sales efforts. They can promote brand awareness by using logos, symbols and slogans about their brands. In addition, businesses should concentrate on product differentiation, new product development or existing product development and improvement activities. Thus, they can build awareness and loyalty to their brands. As a result, businesses can strengthen their brands against competitive threats by creating a high market share.

The research's sample consists of students registered at different faculties of Aksaray University. Another limitation of the study is choosing the mobile phone as a product category. In the follow up studies, the other units of the same university or different faculties of different universities can be included. Besides, the study can be done on different age groups and product categories. In the study, customer based brand equity has been dealt with in three dimensions. In the succeeding studies, brand equity can be dealt with in different dimensions.

\section{References}

Aaker, A. D. (1991). Managing Brand Equity. New York: The Free Press.

Aaker, D. A. (1996). Measuring Brand Equity Across Product and Markets. California

Management Review, 38(Spring), 102- 120.

Ahmad, F. \& Sherwani, N. U. K. (2015). An Empirical Study on the effect of Brand Equity Mobile Phones on Customer Satisfaction. International Journal of Marketing Studies, 7(2), 59-69.

Altunışık, R., Coşkun, R., Bayraktaroğlu S. \& Yıldırım, E. (2004). Araştırma Yöntemleri. 3.Basım, Avcı Ofset, İstanbul. 
Özçifçi, V. (2017). Determining the impact of brand equity on consumer purchase intention. International Journal of Social Sciences and Education Research, 3 (4), 1164-1177.

Atılgan, E., Aksoy, Ş., \& Akınc1, S. (2005). Determinants of the brand equity: A verification approach in the beverage industry in Turkey. Marketing Intelligence \& Planning, 23(2/3), 237-248.

Avcılar, M.Y. (2008). Tüketici Temelli Marka Değerinin Ölçümü. Çukurova Üniversitesi Sosyal Bilimler Enstitüsü Dergisi, 17(1), 11-30.

Ayyıldız, H., Cengiz, E. \& Ustasüleyman, T. (2006). Üretim ve Pazarlama Bölüm Çalışanları Arası Davranışsal Değişkenlerin Firma Performansı Üzerine Etkisine İlişkin Yapısal Bir Model Önerisi. Muğla Üniversitesi Sosyal Bilimler Enstitüsü Dergisi, 17, 21-38.

Baldauf, A., Cravens, K. S. \& Binder, G. (2003). Performance consequences of brand equity management: Evidence from organizations in the value chain. The Journal of Product and Brand Management, 12(4/5), 220-234.

Bilgili, B., Özkul, E. (2015). Brand Awareness, Brand Personality, Brand Loyalty And Consumer Satisfaction Relations in Brand Positioning Strategies (A Torku Brand Sample). Journal of Global Strategic Management, 9(2), 89-106.

Buil, I., Martinez, E. \& Chernatony, L. (2013). The İnfluence of Brand Equity on Consumer Responses. Journal of Consumer Marketing, 30(1), 62-74.

Can, P. (2016). Marka Deneyimi, Hedonik Duygular ve Algılanan Reklam Harcamalarının Marka Değeri Boyutlarına Etkisi Üzerine Fast Food Sektöründe Bir Araştırma, Uluslararası Yönetim İktisat ve İşletme Dergisi,12(30), 121-143.

Chong, V. K., Rundus, M. J. (2004). Total Quality Management Market Competition and Organizational Performance. The British Accounting Review, 36(2), 155-172.

Erdem, T., Swait, J. \& Valenzuela, A. (2006), Brand as signals: a cross-country validation study. Journal of Marketing, 70, January, 34-49.

Farquhar, P. H. (1989), Managing Brand Equity. Marketing Research, September, 24-33.

Gill, M., S., Dawra, J. (2010). Evaluating Aaker's sources of brand equity and the mediating role of brand image. Journal of Targeting, Measurement and Analysis for Marketing, 18(3), 189-198.

Girard, T., Trapp, P., Pınar, M., Gülsoy T. \& Boyt, T. E. (2017). Consumer-Based Brand Equity of A Private-Label Brand:Measuring and Examining Determinants. Journal of Marketing Theory and Practice, 25(1), 39-56.

Hair, J. F. Jr., Anderson, R. E., Tahtam, R. L., Black, W. C. (1998). Multivariate Data Analysis. Fifth Edition. Prentice Hall Inc., New Jersey.

Hooper, D., Mullen, C. J. (2008). Structural Equation Modelling: Guidelines for Determining Model Fit. Electronic Journal of Business Research Methods, 6(1),53-60.

Ishak, F., Ghani, N. H. (2013). A review of the literature on brand loyalty and customer loyalty. In: Conference on Business Management Research,11, 186-198.

Jara, M., Cliquet, G. (2012). Retail brand equity: Conceptualization and measurement. Journal of Retailing and Consumer Services, 19,140-149.

Keller, K. L. (1993). Conceptualizing, Measuring, and Managing Customer-Based Brand Equity. Journal of Marketing, 57(1),1-22.

Keller, K. L., Lehman, D. R. (2003). How do brands create value?. Marketing Management, May/June, 2731.

Keller, K. L. (2013). Strategic Brand Management:Building, Measuring, and Managing Brand Equity(4th ed.). Upper Saddle River, NJ: Pearson Prentice-Hall.

Keskin, H. D.,Yıldız, S. (2010). Tüketicilerin Marka Tercihlerinde Etkili Olan Faktörler İle Marka İmajı'nın Marka Değeri Üzerindeki Etkileri: Trabzon Örneği. Dumlupınar Üniversitesi Sosyal Bilimler Dergisi, (27), 239-254.

Khan, M. N., Rizwan, M., Islam, F., Aabdeen, Z. \& Rehman, M. (2016). The Effect of Brand Equity of Mobile Phones on Customer Satisfaction: An Empirical Evidence from Pakistan. American Journal of Business and Society, 1(1), 1-7.

Kim, H., Kim, W. G. \& An, J. A. (2003). The effect of consumer-based brand equity on firms' financial performance. The Journal of Consumer Marketing, 20(4/5), 335-351. 
Özçifçi, V. (2017). Determining the impact of brand equity on consumer purchase intention. International Journal of Social Sciences and Education Research, 3 (4), 1164-1177.

Kim, J., Hyun, Y. (2011). A model to investigate the influence of marketing-mix efforts and corporate image on brand equity in the IT software sector. Industrial Marketing Management, 40, 424-438.

Kim, W. G., Kim, H. (2004). Measuring customer-based restaurant brand equity: Investigating the relationship between brand equity and firms' performance. Cornell Hotel and Restaurant Administration Quarterly,45(2), 115-131.

Karahasan, F. (2012). Taşlar Yerinden Oynarken-Dijital Pazarlamanın Kuralları,1. Basım, Doğan Egmont Yayıncılık ve Yapımcılık Tic. A.Ş.,İstanbul.

Kocaman, S., Güngör, İ. (2012). Destinasyonlarda Müşteri Temelli Marka Değerinin Ölçülmesi ve Marka Değeri Boyutlarının Genel Marka Değeri Üzerindeki Etkileri: Alanya Destinasyonu Örneği, Uluslararası Alanya İşletme Fakültesi Dergisi,4(3),143-161.

Koçak, A., Özer A. (2004). Marka Değeri Belirleyicileri: Bir Ölçek Değerlendirmesi. 9.Ulusal Pazarlama Kongresi, 6-8 Ekim 2004, Ankara.

Konecnik, M., Gartner, W. C. (2007). Customer-based brand equity for a destination. Annals of Tourism, Research, 34(2), 400-421.

Lakshmi, S., Kavida, V. (2016). Impact of Brand Equity on Purchase Intention of Home Appliances. The IUP Journal of Brand Management, 13 (4), 54-67.

Latha, R. (2016). Service Based Brand Equity and Its Impact on Brand Preferences and Purchase Intention: A Study of Customers of Health Insurance in Thanjavur District. International Journal of Research in Commerce \& Management, 7(10),47-53.

Loureiro, S. M. C. (2013). The Effect Of Perceived Benefits, Trust, Quality, Brand Awareness/Associatıons and Brand Loyalty on Internet Banking Brand Equity. International Journal of Electronic Commerce Studies, 4(2),139-158.

Madhavaram, S., Badrinarayanan, V. \& McDonald, R. E. (2005). Integrated Marketing Communication (Imc) And Brand Identity As Critical Components Of Brand Equity Strategy. Journal of Adversiting, 34(4), 69-80.

Majid E., Zahra M. \& Azade R. (2016). Effect of Dimensions of Service Quality on the Brand Equity in The Fast Food Industry. Studies in Business and Economics, 11(3), 30-46.

Marangoz, M. (2007). Marka Değeri Algılamalarının Marka Yayılmaya Etkileri. Ege Akademik Bakış, $7(2), 459-483$.

Mills, I., \& Williams, A. (2016). Understanding Brand Equity in Campus Recreational Sports:A ConsumerBased Perspective. Recreational Sports Journal, 40(2),120 -132.

Nakip, M. (2004). Pazarlama Araştırmalarına Giriş, 1. Basım, Seçkin Yayıncılık, Ankara.

Nunnally, Jum C. (1978), Psychometric theory, (2 ${ }^{\text {nd }}$ Edition), McGraw-Hill, New York.

Odoom, R. (2016). Brand marketing programs and consumer loyalty-evidence from mobile phone users in an emerging market. Journal of Product \& Brand Management, 25(7), 651-662.

Özdemir, E. K., Güzeloğlu, E. B. (2015). Akıllı Telefonlar Ve Marka Değeri Algıları: Üniversite Öğrencileri Üzerine Bir Araştırma. Uluslararası Sosyal Araştırmalar Dergisi, 8(40), 730-742.

Özkan, M., Solmaz, B. (2015). Mobile Addiction of Generation Z And Its Effects On Their Social Lifes. Procedia - Social and Behavioral Sciences, 205, $92-98$.

Pappu, R. ve Quester, P. (2006). A Consumer-Based Method for Retailer Equity Measurement: Results of an Empirical Study. Journal of Retailing and Consumer Services, 13(5), 317-329.

Pappu, R., Quester, P. G. \& Cooksey, R. W. (2005). Consumer-based brand equity: improving the measurement-empirical evidence. Journal of Product \& Brand Management, 14(3), 143-154.

Prahinski, C., Fan, Y. (2007). Supplier Evaluations: The Role of Communication Quality. The Journal of Supply Chain Management, 43(3),16-28.

Rao, P., Holt, D. (2005). Do Green Supply Chains Lead to Competitiveness and Economic Performance. International Journal of Operations \& Production Management, 25(9), 898-916.

Rasouli, R. (2016). Tüketici temelli marka değeri ile perakendeci temelli marka değerinin karşılaştırılması ve perakendeci temelli marka değerinin marka performansına etkisi üzerine bir araştırma (Ağrı-Iğdır- 
Özçifçi, V. (2017). Determining the impact of brand equity on consumer purchase intention. International Journal of Social Sciences and Education Research, 3 (4), 1164-1177.

Van illerinde süt ürünleri örneği). (Yayınlanmamış doktora tezi). Atatürk Üniversitesi Sosyal Bilimler Enstitüsü, Erzurum.

Sakakibara, S., Flynn, B. B. \& Schroeder, G. (1993). A Framework and Measurement Instrument For Justin-time Manufacturing. Production and Operations Management, 2(3), 177-194.

Sasmita, J., Suki, N. M. (2015). Young consumers' insights on brand equity: Effects of brand association, brand loyalty, brand awareness, and brand image. International Journal of Retail \& Distribution Management, 43(3), 276-292.

Saydan, R. (2013). Relationship between Country of Origin Image and Brand Equity: An Empirical Evidence in England Market. International Journal of Business and Social Science, 4(3), 78-88.

Shafi, S.I., Madhavaiah, C. (2014). Defining Customer-Based Brand Equity: An Evaluation of Previous Studies, Srusti Management Review,7(2),34-39.

Tabachnick, B. G., Fidell, L.S. (2001). Using Multivarite Statistics, Fourt Edition, Allyn\&Bacon, a Pearson Education Company.

Tanveer, Z., Lodhi, R. N. (2016). The Effect of Brand Equity on Customer Satisfaction: An Empirical Study Based on David Aaker's Brand Equity Model. The IUP Journal of Brand Management, 13(3), 43-54.

Taşkın, Ç., Akat, Ö. (2010). Tüketici Temelli Marka Değerinin Yapısal Eşitlik Modelleme ile Ölçümü ve Dayanıklı Tüketim Malları Sektöründe Bir Araştırma. İşletme ve Ekonomi Araştırmaları Dergisi, 1(2), $1-16$.

Taşkın, Ç. (2016). Otomobil Sektöründe Tüketici Temelli Marka Değerinin Ölçümü Üzerine Bir Araştırma. Business and Economics Research Journal, 7(3), 125-136.

Ural, T., Perk, H. G. (2012). Tüketici Temelli Marka Değerinin Kişisel Bilgisayar Satın Alma Niyeti Üzerine Etkisi: Antakya'da Bir Çalışma. Anadolu Üniversitesi Sosyal Bilimler Dergisi, 2(3),11-26.

Vazquez R., Rio A.B. \& Iglesias V. (2002) Consumer-based Brand Equity: Development and Validation of a Measurement Instrument. Journal of Marketing Management 18(1-2): 27-48.

Veronique V. A., Wittlox, F. \& Wee, B. V. (2007). The effects of the Land Use System on Travel Behavior: Structural Equation Modeling Approach. Transportation Planning and Technology, 30(4),331-353.

Washburn, J. H., Plank, R. E. (2002). Measuring Brand Equity: An Evaluation of a Consumer-Based Brand Equity Scale. Journal of Marketing Theory and Practice, 10(1),46-62.

Yasin, N. M., Noor, M. N. \& Mohamad, O. (2007). Does image of country-of-origin matter to brand equity?. Journal of Product \& Brand Management,16(1), 38-48.

Yılmaz, M. K., Bağdigen, S. (2015). Endüstriyel Hizmetlerde Marka Değeri: Muhasebe Yazılım Programı Kullanıcıları Üzerinde Bir Uygulama. Atatürk Üniversitesi Sosyal Bilimler Enstitüsü Dergisi, 19 (3), 233-246.

Yoo, B., Donthu, N. (2001). Developing and validating a multidimensional consumer-based brand equity scale. Journal of Business Research, 52,1-14.

Yoo, B., Donthu, N. (2002). Testing cross-cultural in variance of the brand equity creation process. Journal of Product \& Brand Management, Vol. 11 No. 6, pp. 380-98.

Yoo, B., Donthu, N. \& Lee, S. (2000). An Examination of Selected Marketing Mix Elements and Brand Equity. Academy of Marketing Science Journal, 28(2), 195-211.

Zhang, C., Suhong, L. (2006). Secure Information Sharing in Internet-Based Supply Chain Management Systems. Journal of Computer Information Systems, 46(4),18-24.

http://www.connectedvivaki.com 